УДК $378 ; 371.3$

DOI:

Лариса Попова, старший викладач кафедри англійської мови технічного спрямування №1, факультет лінгвістики НТУУ “Київький політехнічний інститут імені Ігоря Сікорського”

\title{
ЦІЛЬОВЕ ВИВЧЕННЯ ІНОЗЕМНИХ МОВ ВПРОДОВЖ ЖИТТЯ В УМОВАХ ІНФОРМАЦІЙНОГО СУСПІЛЬСТВА
}

У статті проаналізовано сутність і необхідність компетентності для безперервного вивчення іноземноі мови як майбутніми фахівцями, так і тими, хто вже працює за фахом. Констатується, щуо навчання впродовж життя визначається як вся навчальна діяльність, яка здійснюється протягом усього життя з метою поліпшення знань, навичок і компетениій. Висловлюється спостереження, щзо в умовах сучасності слід очікувати збільшення мовних вимог до кваліфікованих фахівців щуо вже працюють. Робиться висновок про необхідність підготовки та впровадження системних кроків, спрямованих на забезпечення формування готовності студентів до навчання впродовж усього життя.

Ключові слова: навчання впродовж життя; іноземна мова; освітній досвід; освіта дорослих, навчальний прочес.

Jim. 7.

Larysa Popova, Senior Lecturer of the English Language for Technical Direction No.1 Department, Faculty of Linguistics National Technical University of Ukraine "Ihor Sikorskiy Kyiv Polytechnic Institute"

\section{LIFELONG FOREIGN LANGUAGE LEARNING FOR SPECIAL PURPOSES IN THE INFORMATION SOCIETY}

The article reveals the essence and necessity of competence to Lifelong foreign language learning of future graduates of education and already working qualified specialists. Lifelong learning is defined as all learning activity undertaken throughout life, with the aim of improving knowledge, skills, and competences. Very often universities have unclear ideas of the learning outcomes to be achieved through their language programmes. At present time it is to be expected that the linguistic demands made on adults (qualified specialists) will increase in quantitative and qualitative terms. The foreign languages learned at school or institute may not be the ones you need for your job or for other purposes later in life. What this means is that foreign language learning should not, cannot stop at the end of tertiary education. Now it is necessary to support and disseminate new methods of teaching foreign languages oriented at adults, their needs in line with the professional context. Preparing, education process and further training must be necessarily performed in compliance with current requirements where the continuous foreign language learning should be an inseparable part of university study, oriented at the area of study and aimed at future professional and job requirements. To sum up, learning foreign languages for specific purposes is becoming the necessity at adults. That for higher education students to be lifelong learners, they must develop a capacity for self-direction, motivation and a disposition toward learning In the future people will need continually to enhance their knowledge and skills, in order to address immediate problems and to participate in a process of continuous vocational and professional development. We are now living in the information society in which the demands are so complex and so rapidly changing that the only way in which we shall be able to resolve them is a process of individual, communal, and global learning throughout the lifespan of all of us. The article states that necessary is to prepare and develop system steps aimed at ensuring the formation of students' readiness to learn throughout life.

Keywords: lifelong learning; foreign language; educational experience; adult education; education process.

П остановка проблеми. У статті розглядаються особливості вивчення іноземної мови дорослими в умовах інформаційного суспільства. Інформаційне суспільство в даній статті це не тільки суспільство, де широко застосовуються інформаційні технології. Це суспільство, яке існує в умовах інформаційних технологій, що впливають майже на усі сфери професійної діяльності та особистого життя людини. Їхній вплив на особливості життя та відчувають навіть ті люди, які з тих чи інших причин не користуються цими інформаційними технологіями для досягнення своїх цілей. Сучасне суспільство неможливо уявити без засобів комунікації та засобів масової інформації. Відповідно, зростає роль іноземної мови, яка, зберігаючи завойовану позицію базового елемента сучасної системи освіти, $\epsilon$ загально визнаним засобом досягнення професійної реалізації особистості. 


\section{ЦІЛЬОВЕ ВИВЧЕННЯ ІНОЗЕМНИХ МОВ ВПРОДОВЖЖИТТЯ В УМОВАХ ІНФОРМАЦЙНОГО СУСПІЛЬСТВА}

Аналіз останніх досліджень і публікацій. Проєкт Закону України “Про освіту дорослих" має на меті створити умови для розвитку освіти дорослих на засадах комплексного розуміння іiі суспільної цінності та значущості, визначити пріоритетні напрями освіти дорослих, які б, зокрема, забезпечили формування у дорослих осіб ключових компетентностей, рекомендованих Європейським Союзом для освіти впродовж життя [4]. Серед інших важливих положень, у статті 5 проєкту Закону щодо пріоритетних напрямів освіти дорослих зазначаються, “напрями освіти дорослих, що забезпечують формування у дорослих осіб: ... мовної та мовленнєвої компетентностей, здатності розуміти, висловлювати та інтерпретувати поняття, факти, почуття та думки в усній і письмовій формі, вести конструктивний діалог та взаємодіяти з іншими людьми засобами рідної та іноземних мов" [4]. Питання освіти впродовж життя ("lifetime learning”), зокрема вивчення іноземних мов протягом всього життя, $є$ предметом дослідження багатьох вітчизняних та зарубіжних науковців (Ю. Лавриш, І. Войтович, Л. Лук’янова, О. Аніщенко, O. Тарнопольський, I. Швець, Т. Шадріна, G. Fischer, P. Jarvis, J. Keevy, B. Chakroun, W. Mackiewicz, L. Varečková та ін.). Ю. Лавриш вказує, що трансформації інформаційного соціуму спонукають, а використання цифрових технологій допомагає формуванню навичок автономного навчання, що сприяє залученню студентів до стратегій безперервної освіти 3 подальшим формуванням лінгвістичних та інформаційнокомунікаційних компетентностей [3]. Вона робить висновок: “Залучення студентів в автономну навчальну діяльність через іншомовне професійне спілкування засобами цифрових технологій дозволяє підвищити показники рівня сформованості умінь професійно-орієнтованого спілкування у майбутніх фахівців" [3, 166]. С. Ізбаш та В. Усатий обгрунтовують у своїй роботі спостереження, що майбутні магістри освіти на етапі активного навчання і засвоєння основ професійної діяльності є загалом мотивовані до навчання впродовж життя, але лише половина 3 них мають високий рівень такої мотивації [2, 224]. Про важливість комплексної мовної освіти та іiї впровадження, розуміння мовної освіти як невід'ємної частини навчального процесу протягом усього життя пишуть Л. Варечкова і Я. Павелкова [7]. Вони вказують на необхідність підготовки, розробки та впровадження відповідних системних кроків, підкріплених нормативноправовими актами та урядовими програмами, освітніми установами за участю роботодавців тощо для задоволення вимог останніх і майбутніх потреб ринку праці [7, 304]. Можливості різнопланової та багатогранної, заснованої на принципі безперервності, освітньої діяльності, спрямованої на вивчення іноземних мов, докладно розглядаються у монографії І. Войтович [1]. Автор представляє накопичений за довгий період роботи досвід створення моделі безперервної іншомовної освіти в системі додаткової освіти закладу вищої освіти, описавши його крізь призму теоретичних і методологічних підходів і основних освітніх документів [1]. Стаття В. Піддячого присвячена дослідженню проблем розвитку андрагогічної компетентності та питанням підготовки компетентних фахівців, здатних до самонавчання, самовиховання $[5,106]$.

Мета статті. У пропонованій статті розглядаються особливості освіти дорослих, зокрема, вивчення іноземних мов протягом життя в умовах інформаційного суспільства. Для досягнення поставленої мети статті були використані теоретичні методи, зокрема: узагальнення та систематизації.

Виклад основного матеріалу дослідження. Інформаційні технології так чи інакше впливають на особливості використання мови (іноземної та рідної) в усіх видах мовленнєвої діяльності (письмо, читання, говоріння, слухання). При цьому спостерігаються як прогресивні, позитивні особливості їх впливу на вживання мови, так і негативні, які ускладнюють сприйняття мови [6]. Наприклад, до позитивного впливу можна віднести широку можливість отримувати зразки письмових текстів різної форми та тематики за допомогою засобів електронної комунікації. Раніше, коли тексти існували у паперовій формі, було нелегко, а іноді для звичайної людини майже неможливо отримати іншомовні тексти відповідної форми та тематики, особливо, якщо йшлося про рідкі мови. Але в умовах інформаційних технологій, коли зразки письмових текстів стають набагато доступнішими, зменшується повага до них, до інформації. Набагато частіше письмовий текст тепер може мати недосконалу форму, важку для сприйняття, хоч і спостерігаються спроби якщо не удосконалення, то спрощення форми передачі інформації, (уникнення багатослівних речень, маловідомих слів, громіздких словосполучень тощо). Однак соціальні обставини (відсутність необхідного часу для літературної обробки тексту, відсутність необхідних знань та вмінь) все ж значною мірою впливають на якість текстів, що ускладнює їх на сприйняття читачем.

Ще одним 3 прикладів негативного впливу інформаційних технологій можна назвати 


\section{ЦІЛЬОВЕ ВИВЧЕННЯ ІНОЗЕМНИХ МОВ ВПРОДОВЖ ЖИТТЯ В УМОВАХ ІНФОРМАЦЙНОГО СУСПІЛЬСТВА}

створення текстів тимчасового використання 3 надлишком інформації, також складних для сприйняття (великі тексти, тексти, в яких один або декілька незначних фактів супроводжуються великою кількістю додаткового тексту). Раніше, коли тексти створювались від руки або за допомогою друкарської машинки або ж друкарського набору, такі багато інформативні тексти зі значним надлишком інформації не могли, як правило, виникати через брак часу, відсутність фізичних можливостей у людини передати у письмовій формі велику кількість інформації за короткий час. Із впровадженням інформаційних технологій, письмові тексти можуть зберігатися на електронних носіях, що дає змогу комбінувати нові тексти (або значні частини нових текстів) 3 готових елементів або шаблонів, у які додаються нові дані. Через це виникають багатослівні тексти, які можуть роздруковуватись дрібним шрифтом на папері або інших носіях, наприклад, на плівці для пакування. За таких умов особи, зацікавлені у створенні відповідних текстів, намагаються враховувати у них якомога більше даних та розмістити цю інформацію на обмеженій фізичній площі. Це може бути вже згадане пакування, а також різноманітні чеки, інші фінансові документи, договори, інші юридичні документи. Можливості створювати таблиці для передачі інформації за допомогою електронних технологій часто пов'язані із виникненням складних документів 3 великою кількістю табличної інформації. Сама собою таблична форма, як правило, вживалась та вживається для полегшення передачі та сприйняття інформації, а також для зручності роботи $з$ нею. Але, надлишок табличного матеріалу, який відносно легко створювати за допомогою електронних технологій, важкий для сприйняття читачем, що часто значно ускладнює роботу з письмовими документами.

У питаннях працевлаштування, виконання якихось робіт або зобов'язань в інформаційну епохузначно зростає використання багатосторінкових договорів, форма яких утворена за допомогою електронних технологій. Часто вони можуть роздруковуватись дрібними літерами на невеликих аркушах паперу. Сьогодні часто навіть для виконання разової роботи однією людиною протягом декількох годин може готуватися договір на чотирьох і більше сторінках дрібним шрифтом. В епоху, коли документи подібного призначення утворювались від руки або за допомогою друкарської машинки (лише у виняткових випадках друкувались бланки типографським способом), таке було просто фізично неможливо.
В епоху інформаційних технологій такі багатоінформативні документи, хоч і дають змогу враховувати багато індивідуальних особливостей конкретних правовідносин, але, особливо коли йдеться про виконання зобов'язань сторін, за умови часто обмеженого часу для ознайомлення 3 документом, ускладнюють сприйняття інформації, особливо якщо вона надрукована ще й дрібним шрифтом. Це вже часто призводило до непорозумінь у процесі виконання зобов'язань партнерів. Сторони договорів у результаті цього можуть бути незадоволені виконанням зобов'язань, що може призводити до певних втрат часу, матеріальних та фінансових ресурсів, знижувати якість матеріальних предметів та послуг, потребувати додаткових юридичних консультацій та судових розглядів тощо. Така ситуація, з одного боку, викликає потребу оптимізації культури створення ділових документів та ведення справ, а 3 іншого, потребує вдосконалення навичок створення та читання (сприйняття) письмових текстів як рідною, так і іноземною мовою, що пов'язано з виникненням нових вимог до мовного вдосконалення. При цьому слід, крім іншого, враховувати, що все частіше виникає потреба не просто прочитати текст та зрозуміти його зміст, але і зробити це у якомога коротший час.

Велика кількість текстової інформації в Інтернеті також обумовлює необхідність вдосконалювати уміння відразу переглядати й оцінювати інформацію. Особливо це важливо при роботі з інформацією іноземною мовою. Може скластися ситуація, коли людина, яка недостатньо володіє іноземною мовою, витративши значну кількість часу для перекладу конкретного тексту, зрештою дійде висновку, що інформація $є$ суттєвою для досягнення поставленої мети. Тим більше, що велика кількість інформації в Інтернеті і без цього створює проблему пошуку необхідних відомостей, що пов'язано зі значними витратами часу навіть для людини, яка досконало володіє мовами. Наведені приклади типових ситуацій, пов'язаних з впливом інформаційних технологій на різноманітні сфери застосування мов, актуалізують потребу вдосконалювати знання іноземної мови з урахуванням конкретних ситуацій. Через це зростає значення вивчення іноземної мови в системі освіти дорослих. Ті чи ті форми навчання можуть бути потрібними для людей, які взагалі не вивчали конкретну мову (а деякі не завжди досконало володіють окремими видами мовленнєвої діяльності рідною мовою), а також і тим людям, які мають відповідну мовну освіту, досвід використання рідної та іноземної 


\section{ЦІЛЬОВЕ ВИВЧЕННЯ ІНОЗЕМНИХ МОВ ВПРОДОВЖ ЖИТТЯ В УМОВАХ ІНФОРМАЦЙНОГОСУСПЛЛЬСТВА}

мови у різних видах діяльності (наприклад, створення різноманітних письмових текстів, усна комунікація, усний та письмовий переклад тощо). Тому мовна освіта дорослих включає і вивчення окремими людьми основ конкретної мови (в такому випадку потрібно визначити, які елементи мови слід знати та опанувати передовсім в обмежений час для досягнення конкретних комунікативних цілей), і вдосконалення мовних знань фахівців, які вже мають і знання основ мови, і мовний досвід, які потребують вмінь, необхідних для якісного створення письмових текстів іноземною мовою, іноді у літературній формі або створення у короткий час текстів, зрозумілих та легких для сприйняття носіями мови, або ж читання великого обсягу спеціальних або загальних текстів 3 витратами найкоротшого часу. Це - своєрідні полюси мовної освіти дорослих - від елементарних знань для тих, хто вперше починає вивчати конкретну мову, до тих, хто бажає створювати високоякісні літературні тексти іноземною мовою, доносити до носіїв мови складні думки в оптимальній формі та зберігати час, охоплюючи великі обсяги інформації іноземною мовою. А між цими полюсами йдеться про вдосконалення конкретних знань та вмінь, необхідних для досягнення комунікативних цілей у практичній діяльності, наприклад, формування навичок, необхідних для створення письмових текстів для повсякденної комунікації, удосконалення сприйняття іноземної мови на слух, вивчення термінології конкретних галузей знань або особливостей текстів, характерних для конкретної галузі знань. Навчання дорослих може здійснюватися у різних формах закладів освіти за різними методиками. Як правило, це заклади додаткової освіти, які не входять до системи середньої або вищої освіти, хоч і можуть діяти при таких закладах. Дорослі, як правило, вже мають відповідну середню або вищу освіту. У випадках, коли певну освіту потрібно здобути для отримання конкретного соціального або професійного статусу, дорослі навчаються (або складають іспити) у конкретних закладах освіти, призначених для надання відповідної “статусної” освіти. Але вивчення іноземної мови дорослими здійснюється, як правило, з метою задоволення конкретної практичної потреби, тому може проходити неформально, без одержання “статусних" документів про освіту. Однак і в такій ситуації існують випадки, коли поряд 3 одержанням фактичних знань та умінь з іноземної мови дорослому учню може бути потрібним ще й документ про навчання та досягнення конкретних результатів. Він звісно може приносити додаткове моральне задоволення, свідчити, що учень виконав відповідні вимоги, перевірив та підтвердив свої знання в процесі іспитів (практик) та отримав визнання своїх досягнень. Документ також свідчить, що людина конкретний час займалася корисною справою, необхідною для професійної діяльності. Це і одна 3 форм письмової фіксації успіхів учня. Часто вивчення іноземної мови дорослими здійснюється індивідуально, без звернення до освітніх закладів. Це може бути індивідуалізоване самостійне навчання, але іноді ефективним може бути спільне навчання 3 іншою людиною, яка також має аналогічні цілі. Таке навчання підсилюється взаємною моральною підтримкою двох людей, часто додається ще й обмін досвідом вивчення іноземної мови, враховуються особливості засвоєння окремих мовних явищ тими, хто навчається. Ефективним, але не завжди доступним, може бути самостійне вивчення іноземної мови за допомогою людини представника цієї мови. Іноді така людина може володіти мовою того, хто за їі допомогою навчається, але таке трапляється не часто. Як раніше, так і тепер цінується обмін мовними знаннями носіїв різних мов. В інформаційну епоху контакти під час вивчення іноземної мови можуть бути як безпосередніми, так і за допомогою технічних засобів комунікації.

Вивчення іноземної мови дорослими - це складний вид розумової діяльності. Тому, крім створення необхідних соціальних умов (наявність вільного часу, інших ресурсів), ефективність роботи учнів може бути значно підвищена оптимізацією фізичного стану людини, що досягається фізичною діяльністю (вправи та системи вправ), відповідним харчуванням, оптимальним співвідношенням праці та відпочинку, спеціальними вправами та методиками для поліпшення пам'яті та розумової діяльності загалом. В окремих випадках така комплексна діяльність може значно сприяти успішному засвоєнню іноземної мови, формуванню необхідних вмінь та навичок. У процесі вивчення іноземної мови дорослими велике значення може мати оволодіння вміннями та навичками створення письмових текстів іноземною мовою. Це важливо й актуально сьогодні, коли значно зростають можливості для міжнародних контактів, в окремих випадках вони можуть стати необхідністю. Не завжди за таких умов $є$ можливості замовляти переклад текстів, тим більш текст, призначений для представлення іноземним читачам, іноді повинен мати іншу форму. Також далеко не завжди можна очікувати, 


\section{ЦЛЬОВЕ ВИВЧЕННЯ ІНОЗЕМНИХ МОВ ВПРОДОВЖЖИТТЯ В УМОВАХ ІНФОРМАЦЙНОГО СУСПІЛЬСТВА}

що в епоху великої кількості інформації на якусь інформацію звернуть увагу іноземці і перекладуть iii своєю мовою. Можна вже не говорити про необхідність для окремих людей тривалий час працювати в зарубіжних країнах, коли їх професійна діяльність пов'язана, окрім іншого, зі створенням високоякісних письмових текстів іноземною мовою, часто у коротший час за умови обмежених інформаційних ресурсів.

Створення письмових текстів високого рівня завжди вважалося високим мистецтвом. Іноді і професіоналам в галузі мови не завжди вдається передати усі свої думки, усі тонкощі справи у письмовій формі. Часто це потребує значної праці над текстом. Але вже частіше трапляються випадки, коли якісні тексти (оригінальні та перекладні) створюються людьми, які вивчили конкретну мову як іноземну, проживають або значний час проживали в умовах іншого мовного середовища. Тому, якщо це необхідно, деякі дорослі намагаються засвоїти іноземну мову для створення високоякісних письмових текстів для досягнення конкретних цілей.

Висновки 3 дослідження і перспективи подальших пошуків. Вивчення іноземних мов упродовж усього життя в умовах інформаційного суспільства визначається одним з пріоритетних напрямів освіти дорослих. Сформовані під час навчання цифрові й мовленнєві вміння допомагають у подальшому формуванні та вдосконалені рівнів іншомовної компетентності. Освіта дорослих є важливим фактором, який сприяє підвищенню конкурентоспроможності фахівців на ринку праці. Здатність спілкуватися професійною іноземною мовою зі своєї спеціальності, володіння кількома іноземними мовами є вагомим підгрунтям для самореалізації у професії або підвищення кваліфікації. Темою для перспективного дослідження може бути вивчення андрагогічних засад післядипломної освіти.

\section{ЛІТЕРАТУРА}

1. Войтович И. К. Иностранные языки в контексте непрерывного образования: монографія / под ред. Т. И. Зелениной. Ижевск: Изд-во "Удмуртский университет", 2012.212 с.

2. Ізбаш С., Усатий В. Компетентність “навчатися впродовж життя". Науковий вісник Мелітопольського державного педагогічного університету. Серія: Педагогіка. 2018. № 1. С. 224-232.

3. Лавриш Ю. Індивідуалізація навчання іноземних мов майбутніх інженерів: концептуальні засади. Освітні обріï. 2020. T. 50. №. 1. С. 164-167.

4. МОН пропонує для громадського обговорення проект Закону України "Про освіту дорослих" (07.09.2020). Міністерство освіти і науки України. URL: https://mon.gov.ua/ua/news/mon-proponuye-dlyagromadskogo-obgovorennya-proyekt-zakonu-ukrayinipro-osvitu-doroslih (дата звернення: 29.03.21).

5. Піддячий В. Методологічні засади розвитку андрагогічної компетентності педагогів у закладах вищої освіти. Молодь і ринок. 2020. № 5(184). С.106-110

6. Попова Л. І. Іноземні мови в освіті дорослих. Молодий вчений. 2018. №4(2). С. 525-527.

7. Varečková L., Pavelková J. Importance of Foreign Languages in Education Process at Universities. Revista Romaneasca pentru Educatie Multidimensionala. 2018. Vol. 10(4), pp. 294-306.

\section{REFERENCES}

1. Voytovich, I. K. \& Zelenina, T. I. (Ed.). (2012). Inostrannyye yazyki $\mathrm{v}$ kontekste nepreryvnogo obrazovaniya: monografiya [Foreign languages in the context of continuing education]. Izhevsk, 212 p. [in Russian].

2. Izbash, S., \& Usatiy, V. (2018). Kompetentnist "navchatysia vprodovzh zhyttia" [Competence "lifelong learning"]. Scientific Bulletin of Melitopol State Pedagogical University. Series: Pedagogy. No. 1, pp. 224 232. [in Ukrainian].

3. Lavrysh, Yu. (2020). Indyvidualizatsiia navchannia inozemnykh mov maibutnikh inzheneriv: kontseptualni zasady [Individualization of teaching foreign languages to future engineers: conceptual principles]. Osvitni obrii. Vol. 50. No. 1, pp. 164-167. [in Ukrainian].

4. Ministry of Education and Science of Ukraine (2020). MON proponuie dlia hromadskoho obhovorennia proekt Zakonu Ukrainy "Pro osvitu doroslykh" [MON proposes for public discussion the draft Law of Ukraine "On Adult Education"]. Available at: https://mon.gov.ua/ua/news/ mon-proponuye-dlya-gromadskogo-obgovorennyaproyekt-zakonu-ukrayini-pro-osvitu-doroslih (Accessed 29 March 2021). [in Ukrainian].

5. Piddyachiy, V. (2020). Metodolohichni zasady rozvytku andrahohichnoi kompetentnosti pedahohiv u zakladakh vyshchoi osvity [Methodological fundamentals of developing andragogical competence of teachers in higher educational establishments]. Youth \& market. No. 5(184), pp. 106-110. [in Ukrainian].

6. Popova, L. I. (2018). Inozemni movy v osviti doroslykh [Foreign languages in adult education]. Young scientist. No. 4 (2), pp. 525-527. [in Ukrainian].

7. Varečková, L., Pavelková, J. (2018). Importance of Foreign Languages in Education Process at Universities. Revista Romaneasca pentru Educatie Multidimensionala. Vol. 10 (4), pp. 294-306. [in English].

Стаття надійшла до редакції 15.03.2021

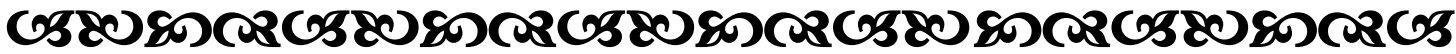

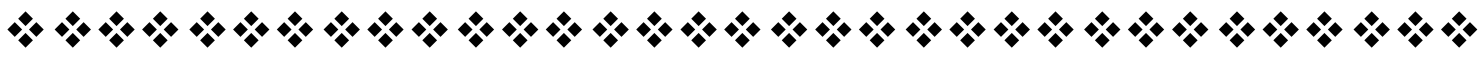

